\title{
The Constitutionalism Movement in Yugoslavia: A Preliminary Survey
}

One of the critically important trends in the government and politics of the East European Communist states in recent years has been the quite steady and rapid development in Yugoslavia of some striking forms of pluralization and institutionalization of power, and of some concomitant fairly well enforced legal restrictions on power. The development is often called by the Yugoslavs their movement toward "constitutionalism and legality."1 However, though Titoism has been much studied, this particular movement," one of the most far-reaching and fundamental of all of the Titoist innovations, has received little explicit examination in Western scholarship, ${ }^{3}$ even in such a colorful

1. Ustarnost i zakonitost; see chapter 7 of the 1963 Yugoslav federal constitution.

2. "Movement" is common in both official and scholarly Yugoslav usage and is probably the best term available, but it may suggest more strength and inevitability in the development than Westerners would be willing to recognize.

3. Thus, though there has been some good journalism, there are few articles in the scholarly journals touching the matter in any depth. Representative of recent books is H. Gordon Skilling's valuable The Governments of Communist East Europe (New York, 1966), which gives the movement little treatment. George W. Hoffman and Fred Warner Neal, Yugoslavia and the New Communism (New York, 1962), though still basic, was published before the 1963 constitutions and numerous other important events affecting the movement. Mention must also be made of Phyllis Auty's admirable Yugoslavia (New York, 1965), but it is addressed to broader issues. Two recent books are

This article is a report of the first results of a continuing study. It began when the writer held a Fulbright research professorship in Yugoslavia in 1965-66. Since then it has received generous support from the American Philosophical Society, Claremont Men's College, the Claremore Fund, and the Henry Salvatori Center; the writer records his thanks to these organizations. Several related aspects of the subject are somewhat speculatively explored in Winston M. Fisk, "A Communist Rechtsstaat?-The Case of Yugoslav Constitutionalism," Government and Opposition, 5, no. 1 (Winter 1970): 41. The writer owes a special debt of gratitude to Professor Jovan Djordjevic of the University of Belgrade and to Professor Fred Warner Neal of the Claremont Graduate School. The study is based almost entirely on participant interviews and direct observation (both now readily possible) in Yugoslavia since September 1965. It is necessarily preliminary and partial, since so little work has been done directly on the subject by Western scholars. It explores the thesis that at least in the Yugoslav setting a Communist regime can generate a form of genuinely constitutional rule, and that the Yugoslav movement may well be a real and lasting affair, and an alternative in the future of Communist regimes. The conclusion so far is that the thesis is about halfway proven, and that some tenable hypotheses about why and how such rule gets generated are now emerging. 
manifestation as the exercise by the new constitutional courts of the power of judicial review over major legislation approved by the party. This article deals with the nature and dynamics of the movement and with some implications it may have.

An influential Yugoslav political scientist and theoretician suggests the central position in the Communist world that the Yugoslavs assign to this movement: "Modern society tends to set up a more complex organization of power, more decentralized and more stable. . . . the institutionalization of political power is, at present, the main and even historical problem of the socialist state and society." 4 The view expressed in this and in the large body of similar Yugoslav statements leads to the quite dramatic assertion the Yugoslavs are now making (which, among other things, runs contrary both to orthodox Communist doctrine and to the usual practice of Communist regimes when fully in power) to the effect that Communist states are similar to other states in this vital respect and that Communist states, as they become modern, contain forces which tend to generate political orders that have, mutatis mutandis, some of the characteristics of classic Western constitutionalism. ${ }^{5}$ This is a large assertion indeed, and its basis needs to be examined.

Ghiţa Ionescu, in an outstanding contemporary analysis of the political dynamics of Communist East Europe as a whole, offers the following as one of his conclusions:

This analysis of the political societies of the European Communist states has concentrated on the study of their present realities. If one were to attempt to forecast their future one would do so by singling out the two features which have shown such a basic continuity in these realities that they might be considered as two irreversible trends. The first is that the pluralization and the reinstitutionalization which follows from it will continue to lead to the dissolution of the Apparat. The second ... is that the European Communist states will in the future become more European than Communist. ${ }^{6}$

This interpretation raises with renewed force the often-discussed suggestion that these Communist regimes, after their messianic, terrorist, and revolution-

Wayne S. Vucinich, ed., Contemporary Yugoslavia (Berkeley and Los Angeles, 1969), and M. George Zaninovich, The Development of Socialist Yugoslavia (Baltimore, 1968).

4. Jovan Djordjević, "Political Power in Yugoslavia," Government and Opposition, 2, no. 2 (February 1967): 207.

5. "Constitutionalism" is a slippery term, but it can be useful. See the clarifying recent discussions by Sartori, Morris-Jones, and Vile: Giovanni Sartori, "Constitutionalism: A Preliminary Discussion," American Political Science Review, 56 (1962): 853-64; W. H. Morris-Jones, Communications, American Political Science Review, 59 (1965): 439-40; M. J. C. Vile, Constitutionalism and the Separation of Powers (Oxford, 1967).

6. Ghita Ionescu, The Politics of the European Communist States (London and New York, 1967), p. 271. 
ary youth, may be slowly headed toward something like a sedate, law-abiding, and respectable middle age.

The Yugoslav movement toward pluralization undoubtedly will influence the general East European trend, whether or not Yugoslavia is a or the "model," or "pattern," or "leader." The Yugoslavs argue that it is none of these, partly from conviction that every country must find its own way to socialism from its own traditions, habits, and "objective circumstances," and partly from shrewd political analysis. ${ }^{7}$ However, they are clearly saying not only that constitutionalism is a natural and inevitable movement for Yugoslavia but also that the other East European Communist regimes will sooner or later move decisively toward constitutionalism and legality.

To be sure, both Ionescu and the Yugoslavs may be overstating the matter, and certainly simple ideas of convergence must be treated with great caution. Further, Ionescu would not want the trends he notes to be projected as something fixed and automatic. In addition, the Yugoslav situation may have significant unique features. And so on. The affair requires careful analysis before we can begin to explain it, let alone make predictions.

At least three major phenomena of contemporary Yugoslavia that are especially vital to the constitutionalism movement because of their pluralizing and institutionalizing effect have advanced considerably beyond their rather small beginnings (if these are in fact real beginnings) elsewhere in Eastern Europe. $^{8}$

One of the three phenomena is that the Yugoslavs are now attempting, probably for the first time in any Communist regime, to govern politically. There is now a good deal of political activity in Yugoslavia in the classic Western sense, a sense well expressed by Bernard Crick: "Politics, then, can be simply defined as the activity by which differing interests within a given unit of rule [e.g., a nation] are conciliated by giving them a share in power in proportion to their importance to the welfare and survival of the whole community." 9 Furthermore-an important point-this political activity goes on to a decisive and increasing degree through the ordinary channels of government and politics (e.g., legislatures, interest groups, executive and administrative organs, public opinion, law, etc.) rather than through party

7. Their most common explanations of their influence are (1) that they are respected because they were the first anti-Stalinists and the first to experiment with devices (e.g., the market) that everyone now agrees are promising and (2) that all the East European countries have some conditions and some problems in common.

8. The movement is of course affected by the whole of Yugoslavia's historical experience and present circumstances-e.g., the nationalities problem, the historical fact of self-liberation, the personalities of Tito and his associates, the country's status as a nonsatellite, and so forth. The three phenomena seem of most immediate causative political relevance, but certainly long and complex chains of causation lie behind them as well.

9. Bernard Crick, In Defence of Politics, rev. ed. (Baltimore, 1964), p. 21. 
or covert channels. And the Yugoslavs in their own thinking have moved away from the simplistic utopianism (and then absolutism) of traditional Marxism-Leninism and apparat rule. They are addressing themselves to the problems of the organization of political power among institutions, at least as much in the manner of Western politicians and political scientists as of orthodox Communists. They have built up a rather developed and potent set of governmental-political institutions which lie in the way of return to authoritarian "administrative" rule. These are prominent realities in contemporary Yugoslavia. There is, not quite but almost, an institutional settlement.

The second phenomenon is the new economic order. All the East European countries have moved away from a postwar economy that was almost totally centralized and Eastward-oriented. The Yugoslav shift-the last major steps taken in the "economic reforms" begun in 1965 and still continuing-is drastic and has been widely discussed. The elements most significant for constitutionalism may be summarized briefly: the federal budget declines in importance nearly every year; the Plan is indicative and predictive only, not detailed and compulsory; the workers' council system and enterprise autonomy are established; investment is now largely out of the hands of the federal government; the market dominates in most fields; and the economy is, as the Yugoslavs say, "entering into the international division of labor." The political power that grows out of economic power has in many respects been decisively pluralized.

The third phenomenon is experimentation. The Yugoslavs have been innovative; many significant methods and ideas in government and politics have been tried out. And many of the experiments are like genies, who once let out of the bottle of authoritarian and ideological rule are hard to force back in. Some of the experiments (e.g., functional representation in legislatures) are old ideas but have rarely been put to the test before. Some (e.g., a constitutional judicature with broad powers of judicial review) are classics borrowed from Western tradition and revised for Yugoslav use. Some (e.g., judicially enforced administrative law for the protection of the citizen against unlawful government action) are fairly standard in the West but are little known in Communist regimes, and have been expanded in Yugoslavia beyond what is customary in the West. Some (e.g., the development of economic law and litigation by specialized courts, much like the medieval law merchant) are startling revivals of the past in today's world. Some (e.g., developed drafting and information services, both technical and policy-oriented, for the legislatures) are methods long thought in the West to be good ideas but seldom adopted. Some (e.g., drastic decentralization and "de-étatization" of government) are more or less new. Some (e.g., workers' self-management in economic enterprises and in all other "working organizations," including 
to a degree even government) are new attempts to apply ideas that in various forms have existed for years in reformist thought. Some (e.g., the new and increasingly more limited role of the party) are revolutionary in Communist thought and practice. Out of such experimentation many elements of the constitutionalism movement have emerged.

It may be held that the political order in Yugoslavia today functions through four main clusters of processes, each with its associated bodies of doctrine and structure of institutions.

The first of these clusters is governmental pluralism. This somewhat unsatisfactory term is intended to include federalism and decentralization but to exclude the curious phenomenon of "de-étatization," which, though related to governmental pluralism, is at root part of the second cluster, social self-government, which in turn, though certainly pluralist, is a social and political matter that stands in a substantial way apart from government. The third cluster is what the Yugoslavs call "assembly government," or the "assembly system." This is the embodiment of Yugoslavia's special version of the old Marxist idea of unity of power. The fourth cluster has to do with the governmental and political side of the legal order. Its most spectacular aspect is the constitutional judiciary, in existence since 1964 and employing with increasing vigor the power of judicial review against both federal and republic action. As we shall see, however, there are many other vital governmental and political uses which the Yugoslavs make of law and the courts.

We shall discuss these four clusters separately, though they are interactive and interdependent. First, however, we must clear up a vital threshold question, that of the position of the party.

\section{The Paity and the Movement}

Usually in an analysis of a Communist regime, primacy is given to the party and its apparat. For some years the Yugoslav party has insisted that in important respects such is not the case in Yugoslavia. That is probably true. With the progress of the constitutionalism movement, the party is no longer the major center of policy formation, decision-making, or policy effectuation, even informally. ${ }^{10}$ The causes for this change need not detain us; the important fact is that it has taken place, freeing our four clusters to dominate the polity.

More and more the party is staying away from everyday governing and politicking. Thus it is fairly well established that nobody (except Tito, an

10. Reservations must be made for basic and long-range policy, for certain policy areas (e.g., foreign relations), and for some emergency situations (e.g., the Rankovic affair), none of which are directly relevant here. 
exception less important than it might seem) may hold high office in both the party and the government. This is not a rule of rigid separation, but certainly deviates sharply from Soviet practice. And most of the party line deals only with broad issues and in broad terms, leaving some room to urge differing policy views without disloyalty to the party. The party, by established and repeated policy, at least formally eschews a role as authority; it asserts that it is no longer "an instrument of power" but an "ideological force" only. Observation and interviews in policy processes bear out this official picture, as do documents drawn from these processes. Matters are especially clear in the complexes of legislative processes which play an important part in the polity. Both general inquiry and specific legislative episodes suggest that, especially at the higher levels, policy is being made by the overt legislative processes rather than offstage in party caucuses. ${ }^{11}$

The party is fully committed in doctrine and in practice to the constitutionalism movement; it sees the pluralization and institutionalization of power as the future of the political order, and expects to find its place in such an order. Its motives are only in part libertarian. The party came to the conclusion years ago that only in the constitutionalism movement could be found the economic dynamism and political stability that Yugoslav socialism must have to survive. This view continues to be reinforced, although the movement is still not accepted by some conservative elements in the party (and interestingly enough is suspected by some semianarchistical young liberals as being "bureaucratic" and too formal).

Thus the Yugoslav constitutionalism movement is an extraordinary course for a Communist regime to have undertaken. If the party does complete, and maintain, this shift from instrument of power in an authoritarian system to merely an ideological and catalytic agent in a more or less constitutional system, something new will have been discovered about the potentialities of Communist rule. Some scholars have begun to discuss the future of the monolithic party, and whether such parties alone can run modern states. ${ }^{12}$ Yugoslav events already are shedding considerable light, and will shed much more, on what may be an alternative.

\section{Governmental Pluralism}

For the Yugoslavs, governmental pluralism begins with federalism, both because of the doctrinal and practical centrality they give to it and because it rests upon some of the most fundamental facts of Yugoslav society-especially the existence of the several major nationalities, with their own territories

11. Several detailed legislative histories were done in the course of the present study.

12. See, for example, the symposium, "The Dead End of the Monolithic Parties," Government and Opposition, 2, no. 2 (February 1967). 
and strongly felt separate histories and traditions. The prewar solution to the problems these conditions produced was suppression and Serbian hegemony. The solution during the period of Communist dictatorship (roughly 1945-51) was suppression, centralization, and an attempt to ignore the whole matter. The current solution, expected to be permanent and likely to be, is a constitutional one-a complex federalism of a special and perhaps unique character along with a decentralization perhaps equally complex and unusual.

At the threshold, however, one encounters doubt among commentators that Yugoslavia's constitutional federalism is of any real significance. The main reasons for this doubt are two. One is the doctrine that federalism is a transitional form, a way station on the road either to consolidation or dissolution. ${ }^{13}$ The second is the doubt that any Communist regime will give up strict and discretionary control. The second point seems not to apply to the Yugoslav party. And the Yugoslavs are making a determined effort to avoid both of the developments that the doctrine of the transitory nature of federalism contemplates. Thus the republic capitals, when we look at specific events and policy issues, are clearly independent and major centers of power. ${ }^{14}$ Indeed, it is significant that many able Yugoslav politicians, well qualified to judge which way the wind is blowing, have left Belgrade and are pursuing their careers in their home republics. The question of stability against dissolution remains, but so far no real tendency toward dissolution can be detected. Though separatist ideas exist, they stop short of real substance.

Yugoslav federalism is not the familiar classic type in which power is distributed between central and constituent governments in supposedly watertight compartments. Rather it is part of a large scheme of cooperative decentralization. For example, the communes (opštine), in theory and it seems increasingly in practice as the constitutionalism movement goes on, are not regarded as permanent creatures or even subdivisions of either the federation or the republics..$^{15}$ Rather they are seen as the building blocks, the natural and basic units of the whole system, dealing directly and on a plane of at least formal and juridical equality with republic and federation alike. ${ }^{16}$ (Thus

13. See, for example, William H. Riker, Federalism: Origin, Operation, Significance (Boston, 1964).

14. One major intention, and probable consequence, of the December 1968 amendments to the federal constitution was to make the republics more independent by strengthening their position in the federal legislature.

15. The communes have been much examined by Yugoslav social scientists, but there is little on them in English. One study by an American scholar is Jack C. Fisher's Yugoslavia: A Multi-National State (San Francisco, 1968).

16. Thus, under the federal constitution of 1963 , the regime's central political as well as legal declaration, the commune is "the basic sociopolitical community" (article 96), "autonomously" passes regulations and determines its own revenues (article 99), and is the repository of all governmental powers not assigned by the constitution to the republics or the federation. 
they draw their status and powers directly from the federal constitution.) Further, this official equality seems often to have some reality; for example, the political muscle that a vigorous commune can show at least in dealing with many of the lesser federation and republic agencies is often substantial, and matters tend to be worked out by negotiation and cooperation rather than by command from the top. ${ }^{17}$ And the movement seems to be toward the communes-for strong economic reasons (e.g., the communes now are the principal founders of new economic enterprises) as well as for reasons of governmental pluralism.

Relations between republics and the federation are increasingly collaborative and cooperative-and constitutionalized. Of particular interest are the recurrent heated disputes between them over "basic" and "supplementary" legislation. These problems arise out of the inevitable frictions of any federation, but specific form is given them by a Yugoslav innovation in the constitutional law of federalism.

Under articles 160 and 161 of the constitution of the federation the federal government can legislate on a wide range of subjects-so wide that at first glance little room seems left for the republics. But there is a catch. Only in two major areas-foreign policy and foreign trade, and the national security-is the federal legislative power exclusive; only there can it enact what are called "complete" or "comprehensive" laws (potpuni zakoni), which can exclude any republic legislation. ${ }^{18}$ The federal government does have a rather undefined power to enact "general" laws (opśti zakoni), but these are hardly laws at all. (They have no binding force, obligate nobody, and create no enforceable rights; they are little more than hortative guides which the republics and communes are expected to take broadly into account in their own legislation.)

The disagreement comes over the "basic" laws (osnovni zakoni). These are real laws, lying between "complete" and "general" laws, and have binding force. They comprise most of the federation's constitutional jurisdiction. But they are intended to be framework enactments only-that is, declarations of general policy-and are almost inoperative until supplemented and made effective by subsequent republic legislation. Thus the federal jurisdiction is sharply limited.

The republics are becoming more and more keenly jealous of their prerogatives of supplementation and effectuation, and they wage vigorous political, bureaucratic, and juridical battles against basic laws which they think go too far and encroach unconstitutionally on republic policy-making territory or,

17. This is strengthened by the communes' very considerable constitutional jurisdiction in the administration of federal and republic laws. See, for example, articles 96 and 101. The republics may be strengthened somewhat by the December 1968 amendments to the federal constitution.

18. See, however, section 2 of amendment 16 of the December 1968 amendments. 
on the other hand, do not go far enough and do not take the responsibility they should under the 1963 constitution's division of powers.

Increasing economic decentralization appears in all the standard indicators. Thus, significantly, investment policy is now largely out of the hands of the federation and into the hands of republics, communes, other sociopolitical communities, independent investment banks created in part by the communities but not ruled by them, and individual economic enterprises.

For reasons such as these Yugoslav governmental life is not simply federal but is pluralized in ways that include but go beyond classic federalism -a system in which decentralization, dependent upon and defined and structured by constitutional principle, has proceeded on a dozen fronts and seems likely to proceed further.

\section{Social Self-Government}

Central to this constitutionalism-based governmental pluralism, but even more fundamental, is the master concept of all Yugoslav political thought and practice and the political mainspring of Yugoslav constitutionalism. This is the radically pluralistic self-government in the sociopolitical communities (i.e., governmental units) and the working organizations (i.e., economic and other institutions). The basic idea has been appearing here and there in Marxist thought for years, connected with the dream of the coercive state withering into some kind of idyllic cooperative socialist commonwealth. The venturesome Yugoslavs, however, with their penchant for translating farfetched Marxist theory into action, put the idea into sweeping practice. The decisive Yugoslav contribution is that their cooperative utopia is to be grounded in a constitutional system rather than dependent upon some indeterminate end to conflict.

To the Yugoslavs, social self-government is a most important phenomenon in their polity. Indeed, some Yugoslav theorists find socialism itself a secondlevel matter, existing for the sake of social self-government and at bottom adopted to make it possible. The roots of social self-government are of course in Marx. But they are seen increasingly by the Yugoslavs as being in an early, "humanistic," anthropologically oriented Marx. It should be added, however, that the Yugoslav theoreticians contend that these humanistic and anthropological strains continue through Marx's later thought and are a vital part of his mature system overlooked by other Marxist scholars, especially those under Russian influence. The Yugoslavs in short, with Yugoslav selfconfidence, see themselves as the true expounders of the whole of the doctrine, and the Russians and their followers as putting forward a version that is both truncated and distorted. ${ }^{19}$

19. This Marxist humanism is usually associated with the advanced and supposedly rather heretical Praxis group, but it is actually more widespread than that and is to be 
Social self-government began in 1950 with workers' councils in industry. It was some time before these groups really worked their way out from under party and government domination. Workers' self-management and enterprise autonomy, another aspect of social self-government, now appear established, perhaps especially the latter $;{ }^{20}$ it is impossible to speak with precision because not enough empirical investigation has been done. Yugoslav social scientists find a high degree of development and strength in these areas, ${ }^{21}$ especially in enterprise autonomy, as do the few Western scholars who have looked at the matter extensively. Evidence collected in the present study is limited but tends to bear this out. For example, the investment banks, so important to the economy and so natural a place for party and government influence to hang on, now function quite independently and are highly influential $;{ }^{22}$ thus the National Bank of Yugoslavia is back to the classic central banking functions, note issuance, monetary policy, and foreign exchange management, along with only a small amount of advising on investment matters when asked.

From industry, social self-government has spread to most aspects of life, even to government agencies and the courts. The newspapers continually report instances in which it has been extended or strengthened. Social life is somewhat further along the road than political life, for most social groups now are self-governing. But political life does not lag far behind. One finds pluralism and cooperativism to an extent never before operative in a Communist political order. The Westerner, however, is not so likely to see parallels with Western pluralism in Yugoslav society as he is to see something more familiar to him than the traditional monolithic communism.

Two tendencies in the thinking behind social self-government constantly appear and must be distinguished. One is toward decentralization, the more specifically federal and governmental aspects of which we have already mentioned; Yugoslav theory and practice extend it broadly into devolution outward and downward of a large number of governmental and political activities. The Yugoslavs tend to hold as a matter of faith, doctrine, and practical conviction the drastic view that many processes of governing are better in the hands of small units, that much of governing really is "the problems of our street," and that larger problems and processes and units are often basically epiphenomena.

found in virtually all circles of Yugoslav thought except the most conservative, which are becoming more and more isolated.

20. This is true despite the still somewhat ambiguous position of the enterprise director, who is in some measure a representative of the governmental units or agencies that founded or regulate the enterprise.

21. Major studies have been carried out by the Institute of Social Sciences of Belgrade and by several of the government institutes for public administration.

22. This has been fostered by the catastrophic failure of the political factories (uneconomic factories established by political influence and for political reasons) and by quiet foreign pressures in connection with international loans and grants. 
The second tendency is toward "de-étatization," a less familiar and even more drastic matter. This is the Yugoslav policy, well developed and vigorously practiced, of transferring as many governmental functions as possible (and the Yugoslavs argue that the possible number is large-startlingly large to the Western observer) to nongovernmental and quasi-governmental organizations, often in the nature of cooperatives. For example, much of social insurance (a large field) has already gone this route. More is expected, and there are newspaper accounts almost daily of new instances of "de-étatization."

The classic Communist practice has been toward centralization and "étatization." The Yugoslavs are reversing it. What is emerging is neither Western nor Soviet.

No useful statistics are available, but the social self-government movement is clearly broad and deep, and seems to be gaining momentum. It is regarded as one of the society's principal weapons in what is for Yugoslav Marxism the greatest task and the greatest challenge: the conquest of man's alienation from his work, society, and government. ${ }^{23}$ The Yugoslavs describe it, with some justification, as a radically new approach for communism to governing and the problem of freedom under government.

Yet social self-government is firmly established. Consider, for example, its political-constitutional position. The 1963 constitutions were major political commitments. They have deeply influenced ideology, public opinion, and government practice, and thus have measurably restricted the power of those who promulgated them. The Yugoslav power-holders, including the party, are now less free than before they committed themselves so unreservedly (as they continue to do) to the 1963 constitutions. After over thirteen years of discussion and experiment, social self-government was in 1963 implanted as deeply into the system by the constitutions and the politics of the constitutionmaking processes as anything could be, aside from socialism itself. Further, this position has been strengthened and defended not only politically and by government and the pressures of public opinion but also by the now potent and independent Yugoslav judiciaries, both regular and constitutional. Indeed, this is one of the principal duties of the constitutional judiciary (of which more will be said in a moment) and understandably so, for a complex and novel body of law, constitutional and otherwise, is required to keep all these complex arrangements in order.

\section{The Assembly System}

Social self-government is the great principle of the Yugoslav political order. What the Yugoslavs call "assembly government," or the "assembly

23. Some proposals are a little bizarre, yet are seriously intended and may well be tried. One, for example, is that sections of highway, when built, would be handed over to nongovernmental enterprises to operate and maintain, with revenues coming from tolls. 
system," is their great principle of governmental organization, ${ }^{24}$ and presents other major aspects of their constitutionalism.

As with social self-government, the assembly system is rooted in Communist doctrine, here the Marxist idea of unity of power, though that particular term is regarded now as a Russian one and inappropriate for Yugoslavia. This idea is that governmental power is to be concentrated in the elected assemblies, with the political executive and the administrative system subordinate and directly responsible to them. Thus the executive is seen as more or less a committee of the assembly, and the assembly as itself supervising the administration.

The Yugoslavs assert that they are seeking democratic rule and political freedom through constitutionally regulated social self-government. The assembly and assembly government are regarded as the capstone of social self-government and one of the greatest means whereby that system is protected and effectuated, because the assembly is the place where all the self-governing entities are represented and interact. Structurally, therefore, the heart of the Yugoslav governmental system and of constitutionalism is the assembly. One may ask if the assembly is much of a political reality in the Yugoslav constitutional scheme, and how it actually functions in the system. The question of political reality has to come first, since only if it can be answered affirmatively do the assembly's functions have any significance.

What of the position of the assembly system within government itself, especially on the crucial issues of relations between the assembly and the political executive and the relative degree of real control the two exercise over the administration? The evidence collected for this study is limited largely to the federal government, so we speak mainly of it, although there is also evidence to indicate that trends in the republics are similar. Several lines of inquiry were explored. Six will be mentioned here briefly.

First, the pronouncements of power-holders and influential theoreticians were examined. These have considerable importance-if the public takes them largely at face value, and it usually does-in committing the regime and in arousing expectations that can be disappointed only at the price of a loss of legitimacy and public support so heavy that the regime would hardly want to pay it unless driven by dire necessity (such as serious internal disruption or external threat). The trend is clear, with no serious reservations or caveats in recent years. ${ }^{25}$

Second, a study was made of the general expression of opinion in news-

24. The principle appears throughout the 1963 constitutions; see, for example, articles 163 and 225 of the federal constitution.

25. The trend was recently reconfirmed by the public debates on the December 1968 amendments to the federal constitution and at the ninth congress of the party in March 1969. 
papers and journals and by intellectuals, working officials, ordinary politicians, and so forth. Here the trend is equally decisive. In ordinary informed, responsible, and moderately influential circles the assembly system is regarded as both accepted and acceptable at its constitutional face value, and as the established future of Yugoslav governmental organization. The significance of this is twofold. First, it adds to the commitment of the regime to the system. Second, it indicates that the system is now entrenched in political ideas; the Yugoslavs would now find it difficult to imagine government in Yugoslavia organized and functioning in any other way.

The third line of investigation is perhaps more concrete: it has to do with the movement of political personages of the upper and middle levels out of the political executive (and even out of offices in the party) and into the assembly. A useful empirical and semiquantitative study could be done, but the evidence seems to indicate that the movement is strong and that politicians see a good future in the assembly.

The fourth area of interest lies in the changing relations between the agencies, the political executive, those associated with the Federal Executive Council (roughly the counterpart of the Western cabinet), and the assembly. The agencies-secretariats, administrations, councils, and so forth-are in many cases moving closer to the assembly and away from the executive. A good example is the federal Secretariat for Legislation and Organization, an agency especially concerned with interrelationships within the government. Interviews and other evidence over several years showed a distinct shift in the agency's perceptions of its role and in its actual functions.

The fifth line of inquiry centers on the assembly committees and commissions. External evidence shows them to have a high level of power, which continues to rise. Internal evidence from interviews indicates that they think of themselves, and rightly, as the real centers of policy-making and as the supervisors of the administration and the executive. In some instances they have not yet been able fully to act as such, but they are mostly pretty well along the road.

Finally, there are case histories of specific episodes of policy-making. These tend to confirm, in the form of concrete examples, the foregoing.

To the Western political scientist this march toward assembly hegemony raises the question of general laws of growth-for example, may the Yugoslavs not be encountering some of the familiar problems of Western legislatures, including those of separation of powers? The Yugoslavs, both theorists and politicians, have been concerned for some time over separation; and two schools of thought, tugging in two ways in the constitutionalism movement, have emerged. Both accept an independent and powerful judiciary, which Yugoslavia now has.

One school is the more orthodox and traditional. It holds that social 
self-government and an independent judiciary plus (a Marxist touch) a classless society are enough to protect against all the dangers separation is said to protect against. Indeed to some extent this school continues to accept the usual Marxist argument that separation is merely a bourgeois device to help prevent the working class from reaching power. But this school is uncomfortable; it is as aware as anyone of the distortions and tyrannies that have sprung up in other Communist regimes.

The other school of thought has the advantage of the argument on this point. It contends that there are still conflicts and contradictions in Communist societies, including Yugoslavia, and that they produce oppression and distortions against which separation in the proper form and amount is helpful, as irresponsible executives and nominally supreme but actually feeble assemblies elsewhere in Communist East Europe have not been. This school sometimes goes a step further and argues that proper separation can be of permanent value both to competent government and to freedom, and for the protection of political rights (including the vital right of social self-government) against the much-hated "Stalinism" and "bureaucratism."

The issue now is being brought into sharp focus by the problem of responsibility. The 1963 constitutions provide that executive officials are to be "responsible" for the discharge of their offices. High on the current agenda is the enactment of statutes effectuating this. But the point is made that an executive official cannot justly be held responsible unless he has some independence-which entails some separation, as does the necessity of having an agency of government able effectively to bring him to account.

The upshot is that political scientists can look forward to a most illuminating working out in practice of one of the classic issues of the discipline, and to the first real attempt by a Communist regime to grapple in concrete terms with this issue.

The same is true of another important issue: what should be the internal organization of a legislature? The Yugoslavs recognize that their particular constitutionalism requires an effective legislature, and they have been working on the matter. The novel 1963 constitutional scheme for the federal assembly has been further developed by practice and by the April 1967 and December 1968 amendments, and the republics are following suit. The 1963 scheme provided at the federal level (the republics were similar, mutatis mutandis) one chamber of general jurisdiction, the Federal Chamber representing the communes and the republics, and four specialized chambers representing the working organizations in four major fields-the economy, education and culture, social welfare and health, and social self-government. There was a Chamber of Nationalities incorporated, more or less, in the Federal Chamber and representing the republics. The 1967 amendments strengthened the Cham- 
ber of Nationalities, and the 1968 amendments dropped the Federal Chamber in favor of a further strengthened Chamber of Nationalities, now the chamber of general jurisdiction. Throughout, legislation (with some exceptions) was and is adopted by the general chamber and the relevant specialized chamberthe two acting together as a bicameral body.

This scheme of combined general and functional representation has been in operation long enough to make some tentative conclusions possible. It produces a high level of expertise in committee work and floor debate, and has brought into legislative life in the specialized chambers some highly qualified people who would not be likely to take posts as general legislators, thus improving both the quality and the legitimacy of the assembly in general. And the device of having the general chamber, the chamber of the generalists, the professionals, the politicians, and the functionally specialized chamber, representing subject-matter expertise and the interests of the concerned groups, all work together seems to be operating well and productively.

As to the actual legislative process, the Yugoslavs, in their quest for legislatures competent to play the large role that the constitutionalism movement envisions for them, have made two striking innovations. One is procedural, dealing with the forms and stages in which proposals are considered. Traditional procedure, followed in most Western legislatures, is for a proposal to be drafted as a complete bill and then considered in that form throughout the legislative process. The Yugoslavs employ an ingenious departure. A proposal passes through several distinct forms of drafting, usually beginning as a collection of rather general and broadly phrased "theses" and moving only slowly and by stages into bill form. It goes through several equally distinct stages of discussion and debate, moving from policy to specifics, before enactment. One's impression is that this process helps to produce well-structured and fruitful discussion, often better than what emerges in some of the long-established and more experienced legislatures of the West. An understanding of the Yugoslav procedure helps in part to explain a matter which often raises Western suspicions - the near unanimity of the final votes. Differences and opposition have been compromised, argued down, or abandoned as hopeless in earlier stages, rather than simply repressed or excluded from debate, in the familiar authoritarian style-though traces of this may survive in some forms. Certainly the innovation increases the effectiveness of assembly influence over policy.

A second innovation with significance for policy control is the provision of two kinds of drafting and advisory services. One is the Secretariat for Legislation and Organization. Standing between the agencies (and to a lesser extent the political executive) and the assembly, this secretariat assures that all legislative proposals, at all stages, reach debate only after expert legal scrutiny 
and effective administrative-executive discussion, and with full documentation both from the agencies involved (and the political executive to whatever extent it is involved) and from the earlier stages of legislative consideration.

The second kind of service is the Legislative-Legal Commission. This is a small bureau of highly qualified legal experts attached directly to the assembly. Its function is not to do the routine drafting-though it does a little-but to review proposals in the light of existing legislation and policy. The commission is very influential, and very competent. The Yugoslav legislature is thus in several respects well armed for its dealings with both the political executive and the administration and for its constitutional role as the center of policymaking and supervision. ${ }^{28}$

\section{Law and Constitutionalism}

The most spectacular manifestation of the legal-judicial element in the Yugoslav political order, and in some respects the crown of the constitutionalism movement, is the work of the constitutional courts, the first and so far the only ones in any socialist state. They were established under the 1963 constitutions, one in each republic and one for the federation. The latter so far is much the most important. The constitutions provide extensive judicially enforceable standards both for the limits of the powers of government and for the relationships of the various parts of government to each other-that is to say, for two of the great traditional functions of constitutionalism, the garantiste function and the frame-of-government function. ${ }^{27}$ The constitutional courts are given broad duties, and broad powers, to enforce these standards. (Thus they have the power of judicial review over virtually all acts of government, including all legislation in both areas, along with what appears to be ample political and procedural resources to make this power effective.) These powers the courts have exercised quite vigorously.

The jurisdiction of the federation court is extensive, and a mixture of the political and the judicial. In part it is a court in the traditional style, in part it is a high constitutional council, and in some part it is an unusually powerful and high-level complaints bureau. It is also a vital coordinating commission,

26. One must not be too sanguine; the assembly has a long way to go before it achieves the assured power and expert skill of a Commons or a Senate, and it may fall prey to Western legislative ills (e.g., obstructive committee empires, democratic face versus oligarchic core, and the rest). And of course it always will be profoundly different from them-built on and serving profoundly different social and political orders. But it is developing, and in interesting ways. For example, if and when some form of effective opposition develops in Yugoslavia (and there are a few small signs, emerging out of the constitutionalism movement), its center may well be in the legislature and its shape and functions influenced by that setting.

27. Sartori, "Constitutionalism," pp. 853-64. 
charged with the task of general supervision of Yugoslavia's exuberantly complex governmental system. The court has exercised this jurisdiction actively, and it seems likely to continue to do so. Its own inclinations clearly lie in this direction, public criticism has advocated that it be even more forceful, and the evidence is that the party and other influential circles are fully committed to its support.

The court was created for two major purposes: (1) to serve as a great agency to mediate, coordinate, and keep in constitutional order the tumult of forces released by federalism, the assembly system, decentralization, social self-government, and "de-étatization," and (2) to be a judicial and political defender of constitutionalism and law against the "bureaucratic" use of power by officials and government. ${ }^{28}$

For various reasons the court began with rather minor matters, and felt its way both in its substantive powers and in its procedure. ${ }^{29}$ In recent years it has developed more confidence and has been moving energetically into substantial undertakings. For example, in June 1967 the court for the first time held as unconstitutional major portions of important federal laws, and this in the conceptually difficult and politically hot area of federation-republic relations.

Some changes in the statute of the court and in its constitutional provisions are currently in progress. They are rather minor. But major expansion and strengthening of the court's functions and powers are to come soon. It is a going, prospering, and developing concern.

So far the court has been concerned primarily with the frame-of-government aspect of its constitutional jurisdiction-with federalism, social selfgovernment, and the logic and interrelationships of the constitutional system generally. One large task involving all three has been to see that the complex masses of legislative materials produced by Yugoslav "normative activity" under governmental pluralism, the assembly system, and social self-government are ordered and rationalized in terms of the federal constitution-a detailed, carefully drafted, and demanding legal document as well as a broad political statement. Progress has been made. Yugoslav law is getting into pretty good constitutional order.

Important developments are apparently under way in another of the court's major jurisdictions, and one central to the garantiste aspect of constitutionalism, epitomized in its power to "safeguard . . . basic freedoms and rights established by the constitution" (article 241 of the federal constitution). The court has moved slowly here but is beginning to gather momentum as it gets

28. See Winston M. Fisk and Alvin Z. Rubinstein, "Yugoslavia's Constitutional Court," East Europe, July 1966, pp. 24-28, at p. 24.

29. This and much of what follows is largely based on interviews with court members and others beginning in 1965. 
its other tasks in hand and develops its procedural machinery for handling cases in this class-usually quite individual matters turning upon specific sets of facts.

In all its categories of cases the court is having increasing success in getting its decisions recognized as not only disposing of the particular matter but also as authoritative precedents for other courts and for government agencies and entities, some of which have been stubborn on occasion and jealous of their democratic prerogatives. The court has been firm and in the end largely successful.

The court has another great area of constitutional power and responsibility which, unlike its others, has no American parallel. At first glance it is likely to cause the American observer concern that it would divert too much of the court's energies into political functions as a constitutional advisory council and academic functions as a research center in constitutional law, or even seriously impair its independence and detachment as a court. This function is the court's power and duty to "keep itself informed" concerning events bearing on the effectuation of constitutionalism and legality and to "offer to the Federal Assembly its opinions and proposals to pass laws and take other measures to secure constitutionality and legality and to protect the ... freedoms and rights of the citizens and organizations" (article 242).

So far, however, the court has coped well with its many roles. It began by establishing itself as a court, with strictly judicialized procedure, producing a flood of case decisions and adhering meticulously to judicial style generally. It has recently begun to allow itself more latitude, but without reducing its judicial air. And its recommendations to the assembly have had much impact, both on legislation and on public opinion.

The Yugoslavs have also developed other innovative legal-judicial institutions in their quest for effective "constitutionalism and legality" within a Communist state. One which is rather mundane and technical but whose importance must be counted high is the system of administrative law and litigation.

The Yugoslav constitutional judicature is in part the result of borrowings from the West, notably from America, and in part the creation of contemporary Yugoslav imaginativeness. The system of administrative law and litigation has older domestic roots. However, it is nearly as much an innovation in the Communist world as the constitutional judicature. ${ }^{30}$ The problem of imposing on the administration legal controls that are effective and just without crippling the administrative process is a conundrum that besets all developed polities.

30. The Russian procuracy, for example, is an internal administrative control and a tool of the state, not a system of judicial control of administrative action as the Yugoslav judicature is. See Glenn G. Morgan, Soviet Administrative Legality (Stanford, 1962). 
Working partly imaginatively and partly with inherited materials, and under the impulse of the constitutionalism movement, the Titoists seem to have created a rather satisfactory solution.

Yugoslavia's tradition in both major branches of administrative law-the setting of legal standards for administrative behavior and their enforcement by judicial action-goes back to the Council of State of the Serbian kingdom of the 1860s and to the Austro-Hungarian heritage in the northwest. It was strong in the interwar period, when the judiciary and the Council of State were among the few really respected segments of that troubled monarchy. The tradition was decisively built upon by the Titoists. It survived even the postwar dictatorship, and then was brought into prominence when the movement toward legality, and later constitutionality, began about $1951 .^{31}$

In 1952 the federal law on administrative disputes (amended and strengthened in 1965) was enacted. For the first time in any Communist regime the courts were given substantial independent control over administrative actions. Until then the standard Communist doctrine had been that the courts and the administration were to be completely separate, with the administration controlled only by itself and by the organs of popular power, which commonly meant in practice no effective controls at all. The 1952 statute established judicial control of administrative procedure, building on what had existed. The 1957 law on general administrative procedure (also amended and strengthened in 1965) codified the rules for administrative procedure itself-the internal rules for justice within the administrative machine.

Much has been drawn, in Yugoslav tradition and in the two statutes, from French and Austrian sources and from the civil law generally. But much is specifically Yugoslav. Further, the Yugoslav system in many respects goes beyond existing models, and gives Yugoslavia a system of administrative law and judicial enforcement which compares well with most other systems in justness, effectiveness, and modernity.

The enforcement of the two statutes and the rest of the corpus of administrative law (which is large, because case law, received doctrine, and special statutes all play important roles) is in the hands of special departments of the republic and federation supreme courts, and makes up roughly a quarter of their work. Such empirical studies as exist (the Serbian Institute for Public Administration did an extensive one), and interviews with informed participants and scholars, suggest that enforcement works well and is now independent of undue political influence. Individuals and organizations litigate against all manner of governmental and quasi-governmental agencies and win a fair proportion of the cases. An examination of a number of case files and of a

31. It is significant that one is often told in Yugoslavia that many of the present leading administrative law scholars and judges got their training in the interwar Council of State. 
larger number of judicial decisions in several courts suggests that the cases are substantial, well argued, and well decided. Further, the evidence is that the administration is in general law-abiding-this is strongly borne out by interviews with judges-with cases being litigated in the main over legitimate differences of opinion.

Yugoslav administrative law also features another protective aspect. Every Yugoslav enterprise, or other entity using social property, is subject to the federal Social Accounting Service, which has broad powers of inspection and surveillance and is charged with assuring that social property is used in authorized fashion and for authorized purposes. This powerful agency is, however, also subject to a developed system of administrative law. Here again the performance of the law, the courts, and the agency itself seems creditable.

In summary, Yugoslavia seems in important and far-reaching respects to be becoming a Rechtsstaat. Of the alternatives open to a Communist political order situated as it is, it has made this unlikely choice. Subject to sharp limitations dictated by its ideology, history, and circumstances (it is a smallish and rather poor Communist country, with severe internal strains and also with all the deep problems of its location in Southeast Europe, trying to overcome centuries of underdevelopment and misrule and experimenting with a novel and shaky system), Yugoslavia has elected to commit its political future in major respects to a form of constitutionalism and rule of law. ${ }^{32}$ Whatever one may think of constitutionalism as a basis for organizing government and politics, or of conceptualizing them-and schools of modern political science have doubts on both scores-the Yugoslavs have taken the plunge. Their adventures should be followed with interest. Unlike other Communist nations, Yugoslavia has adopted law and constitutionalism, as contrasted with ideology, administration, apparat, or party, as the primary means of social coordination, organization, and control, and as the means and language of its politics. And law and constitutionalism have become to a degree what Deutsch calls "the nerves of government."33

Yugoslav constitutionalism is a challenging and unusual movement in contemporary politics, especially in the Communist world. We conclude with a rather speculative comment about its causes.

A grand question is, When does political freedom emerge, and survive?

32. This asserts that the 1963 constitutions are important and are, so to speak, genuine-not mere propaganda or misleading façades. However, these documents need to be read with some care. They are political and social pronouncements. As the Yugoslavs say, they are constitutions of a society as well as of a legal order. As such pronouncements, they appear to the casual observer to be suspiciously full of windy political rhetoric. But they are intended to be legal instruments as well, and when they are read in this light the political rhetoric falls into its proper place and one sees the sharply reasoned and precisely drafted legal framework. To this framework the Yugoslav regime has committed itself, beyond possibility of withdrawal except at a heavy price.

33. Karl W. Deutsch, The Nerves of Government (New York, 1966). 
Yugoslavia has a considerable degree of it, as things go in Communist East Europe, and seems to be maintaining it and acquiring more. ${ }^{34}$ Hoffman and Neal (in Yugoslavia and the New Communism) established the accepted causal analysis of this aspect of Yugoslav affairs through 1962. But their analysis does not fully explain the constitutionalism movement.

Berman and Hazard and others have shown that, contrary to oversimplified ideas of the extent of Soviet totalitarianism, the Soviet Union does have an effective and important system of law..$^{35}$ But Yaney has shown that Russia has never had, and does not now have, a genuine legal order, "a commonly recognized legal system based on abstract governing principles," and that this has been one vital cause of the continuing Russian tradition of autocracy. $\mathrm{He}$ says, "Soviet and tsarist statesmen alike have generally regarded themselves as preservers of their people's 'freedom.' They have always assumed in practice that society by itself was not free, that individual subjects were unable to protect their own interests except by appealing to persons in power. ... In such a milieu only the ruler and his favorites have stood for 'freedom." "36 And this is because of the lack of a legal order on which to build more liberal states, because such states have to be built on generally accepted legal relationshipswhich cannot be created out of thin air by government fiat. So Russia has always been governed autocratically.

Herein lies a decisive difference. The Titoists, partly consciously and partly unconsciously, make the opposite assumption, and see in their country a legal system on which to build. And for good reason. The comparative richness and strength of the Yugoslav legal order and its traditions are apparent both from direct experience and from the literature. ${ }^{37}$ Not many contemporary Western political or social scientists recognize a legal order as a major independent variable, a great causative social and political dynamic in its own right. But all astute tyrants, Stalinist and otherwise, have shown that they recognized it as such when they make its corruption a first order of business as soon as they come to power.

34. We will be more sure of this if the 1968 amendments to the penal code, giving Yugoslavia one of the most enlightened systems of criminal procedure in Europe, are fully applied in political cases.

35. See, for example, the convenient summaries of their basic work in Harold J. Berman, Justice in the U.S.S.R., rev. ed. (Cambridge, Mass., 1963), and John N. Hazard, Isaac Shapiro, and Peter B. Maggs, The Soviet Legal System, 2nd ed. (Dobbs Ferry, N.Y., 1969). See also Hazard, Law and Social Change in the USSR (London, 1953).

36. George I. Yaney, "Law, Society and the Domestic Regime in Russia, in Historical Perspective," American Political Science Review, 59 (1965): 380 and 383, emphasis added.

37. Some sense of this can be obtained even from the dryly precise bibliographical entries in Fran Gjupanovich and Alexander Adamovitch, Legal Sources and Bibliography of Yugoslavia (New York, 1964), and the latest of these entries are for 1961, when the current renaissance in the creation, and study, of Yugoslav law was just beginning. 